University of Nebraska - Lincoln

DigitalCommons@University of Nebraska - Lincoln

$12-1994$

\title{
Host Specificity of Rhabdochona canadensis (Nematoda: Rhabdochonidae) in Nebraska
}

\author{
Michael A. Barger \\ Peru State College, MBarger@peru.edu \\ John J. Janovy Jr. \\ University of Nebraska - Lincoln, jjanovy1@unl.edu
}

Follow this and additional works at: https://digitalcommons.unl.edu/bioscijanovy

Part of the Parasitology Commons

Barger, Michael A. and Janovy, John J. Jr., "Host Specificity of Rhabdochona canadensis (Nematoda: Rhabdochonidae) in Nebraska" (1994). John Janovy Publications. 22.

https://digitalcommons.unl.edu/bioscijanovy/22

This Article is brought to you for free and open access by the Papers in the Biological Sciences at DigitalCommons@University of Nebraska - Lincoln. It has been accepted for inclusion in John Janovy Publications by an authorized administrator of DigitalCommons@University of Nebraska - Lincoln. 


\section{Host Specificity of Rhabdochona canadensis (Nematoda: Rhabdochonidae) in Nebraska}

Michael A. Barger and J. Janovy, Jr., School of Biological Sciences, University of Nebraska-Lincoln, Manter Hall 348, Lincoln, Nebraska 68588-0118

\begin{abstract}
Intermediate and definitive host specificity of Rhabdochona canadensis in Nebraska were investigated. Mayfly nymphs Trichorythodes sp. and Caenis sp. were found to serve as experimental intermediate hosts. Development inside the nymphs required approximately 10 days, with the worms passing through 2 molts and then becoming encapsulated in the hemocoel as infective third-stage juveniles. Survey data revealed that only the red shiner Cyprinella lutrensis serves as definitive host for $R$. canadensis in nature. Laboratory infections of Notropis dorsalis, $N$. stramineus, and Fundulus zebrinus, all of which were uninfected in nature, were attempted to determine if observed specificity was due to physiological or ecological factors. Two individuals of $N$. dorsalis became infected with $R$. canadensis, but no development was observed. Both $N$. stramineus and $F$. zebrinus were incapable of becoming infected. Thus, definitive host specificity in this system seems to be mediated by both physiological and host ecological factors.
\end{abstract}

Rhabdochona canadensis is an intestinal nematode of the red shiner Cyprinella lutrensis, commonly found in rivers of Nebraska. Rhabdochona canadensis was originally described by
Moravec and Arai (1971) from Hybopsis gracilis collected in the province of Alberta, Canada. Only 2 other reports of $R$. canadensis have been made, 1 from Texas (Moravec and Huffman, 1988a) and 1 from Michigan (Muzzall et al., 1992). The life cycle of $R$. canadensis has not been studied, and life cycle data on other members of this genus have just recently begun to accumulate. Juvenile Rhabdochona spp. were described by Weller (1938), Shtein (1959), Janiszewska (1960), Vojtkova (1971), Moravec (1972, 1976, 1989), Moravec and Huffman (1988b), and Byrne (1992), but only Moravec (1972, 1976) and Byrne (1992) have experimentally completed the life cycles of members of this genus. Intermediate hosts of Rhabdochona spp. are primarily mayflies, although $R$. longleyi may use troglobitic crustaceans as intermediate hosts (Moravec and Huffman, 1988b).

Surveys have revealed a wide range of definitive hosts utilized by Rhabdochona spp. For in- 
stance, $R$. cascadilla has been reported from over 10 different definitive hosts (Gustafson, 1949; Moravec and Arai, 1971), whereas $R$. phoxinus infects only 1 fish species (Moravec, 1972). However, few experimental infections have been attempted on potential definitive hosts not infected in nature. When these experiments are performed, the results will reveal whether seemingly host-specific parasites cannot infect "odd" hosts due to physiological factors or whether these hosts are simply not becoming infected in those localities because of host ecological factors, such as food preference and microhabitat differences. The purpose of this study was to identify the intermediate hosts of $R$. canadensis in the Platte River of western Nebraska and establish the nature of the observed specificity. To accomplish these goals, the following were performed: (1) a definitive host survey was conducted to confirm specificity in nature; (2) possible intermediate hosts were experimentally infected to discover intermediate host specificity; and (3) possible definitive hosts not infected in nature were experimentally infected to determine whether host distribution in nature is due to physiological or host ecological factors.

Eight species of fish and 11 species of invertebrates were collected from 3 sites on 2 rivers in western Nebraska and 1 site in a mediumsized stream in eastern Nebraska. Fish were seined and invertebrates were collected using an aquatic dipnet. Sites 1 and 2 were on the South Platte River, $2 \mathrm{~km}$ south of Paxton, Keith Co. (Sec. 8, T 13N, R 35W) and $5 \mathrm{~km}$ east of Roscoe, Keith Co. (Sec 7, T 13N, R 36W), respectively. Site 3 was on the North Platte River, $4 \mathrm{~km}$ south and east of Lewellen, Garden Co. (Sec 33, T 15N, R 42W). Site 4 was on Middle Creek, $5 \mathrm{~km}$ west of Lincoln, Lancaster Co. (Sec. 30, T 10N, R 6E). Fish for use in the survey were dissected immediately, and prevalence (percentage of hosts infected) and mean (total number of parasites/ total number of hosts) \pm 1 SE were calculated. Fish and invertebrates for use in experimental infections were maintained in 10-gallon aquaria or gallon jars until needed.

Gravid $R$. canadensis were obtained from $C$. lutrensis. Batches of 10 females were dissected in tap water, releasing unembryonated eggs. The eggs were pipetted into small glass vials and allowed to embryonate. The embryonated eggs were then pipetted into medium-sized finger bowls, along with a small amount of detritus, plant material, and 50-100 conspecific invertebrates. The invertebrates were maintained in this manner for $24 \mathrm{hr}$ and then moved into gallon jars. The invertebrates were then inspected at intervals of $24 \mathrm{hr}, 3$ days, 6 days, 8 days, and 10 days postexposure for the presence of juvenile $R$. canadensis. Because invertebrates were collected from sites where $R$. canadensis naturally occurs, survey data were used as controls. Prevalence between the 2 groups was compared using a $2 \times 2$ contingency table, with Yates correction. The Wilcoxon rank-sum $W$-test was used for testing differences between means. All differences were considered significant and $P \leq 0.05$. Once appropriate intermediate hosts were found, they were then used as positive controls for other invertebrate infections to ensure the infectivity of the eggs used.

Fish to be infected experimentally were placed individually in glass jars along with 10 experimentally infected mayflies and kept for $24 \mathrm{hr}$, allowing the fish to feed on mayflies. The number of mayflies eaten by each individual fish was recorded, and the fish were moved to 10-gallon aquaria and maintained on commercial fish food. Individuals were dissected for the presence of $R$. canadensis at various intervals depending on the number of fish used in a single trial. Fish used, number of trials, and fish per trial were as follows: C. lutrensis (1 trial of 11 fish); sand shiners, Notropis stramineus (1 trial of 7 fish); bigmouth shiners, Notropis dorsalis (1 trial of 2 and 1 trial of 5 fish); and plains killfish, Fundulus zebrinus (1 trial of 5 fish). Again, due to the natural infection of $C$. lutrensis, a controlled experiment was performed using survey data for controls. Prevalences and means were examined statistically as described above for intermediate host infections.

Eggs of $R$. canadensis were unembryonated when dissected from gravid $R$. canadensis; they became embryonated within 15 days after storage in tap water at room temperature. Eggs were oblong and possessed 2 long filaments, 1 at each pole. The filaments were not observable while the eggs were in the uteri; rather, they appeared upon release. Only 2 ephemeropterans, Trichorythodes sp. and Caenis sp., became infected and supported development of juvenile $R$. canadensis. Prevalence and mean \pm SE of the control group were $2.5 \%$ and $0.05 \pm 0.05(\mathrm{n}=40)$, respectively. Fifteen Caenis sp. and 15 Trichorythodes sp. were infected to ensure that the eggs were infective. Prevalences and means $\pm \mathrm{SE}$ were $100 \%$ and $20.33 \pm 2.40$ for Caenis sp. and $100 \%$ 
TABLE I. Experimental infections of 3 definitive hosts not infected in nature.

\begin{tabular}{lcccc}
\hline \multicolumn{1}{c}{ Species } & Mean no. & $\begin{array}{c}\text { Meayflies } \\
\text { mayfera- } \\
\text { eaten } \\
\text { (range) }\end{array}$ & $\begin{array}{c}\text { Preva- } \\
\text { lence } \\
(\%)\end{array}$ & Mean \pm SE \\
\hline Notropis dorsalis & 7 & $1.71(0-6)$ & 28.6 & $5.57 \pm 5.25$ \\
Notropis stramineus & 7 & $3.86(1-6)$ & 0 & 0 \\
Fundulus zebrinus & 5 & $2.60(2-3)$ & 0 & 0 \\
\hline
\end{tabular}

and $19.73 \pm 1.62$ for Trichorythodes sp. Differences were significant between control and experimental groups for both prevalence $\left(\chi^{2}=45.7\right.$, df $=1$ for both Caenis sp. and Trichorythodes sp.) and mean ( $\mu=0 ; \mathrm{n}=15,40$ for both species). Positive controls for use with other infections always showed a significant increase in prevalence and mean over those values found in nature. Other invertebrates exposed to eggs of $R$. canadensis in these experiments were the ephemeropterans Heptagenia diabasia and Isonychia sp., the trichopterans representing Brachycentrus sp. and Leptocercidae, 2 species of Plecoptera, and the crustaceans Daphnia sp., Hyalella azteca, and Asellus sp. When ingested by Daphnia sp., the eggs of $R$. canadensis hatched, but no further development of the juveniles occurred and the worms were lost over time. No other invertebrates exposed became infected. Once eaten by either of the mayfly species, the eggs hatched and the first stage juveniles penetrated the intestinal epithelium with the aid of a small dorsal tooth. In the viscera of this host, the juveniles passed through 2 molts in a period of 810 days and then were encapsulated as thirdstage juveniles. At this point, worms were infective to the definitive host as shown by experimental infections (discussed below). Multiple juveniles per capsule were common; the maximum number of juveniles in a capsule was 10 .

Eight species of fish representing 7 genera occurring in 3 rivers were surveyed in order to confirm host specificity in nature. Prevalences and means $\pm S E$ in red shiners taken from 3 sites were as follows: $50 \%$ and $1.47 \pm 0.43(n=30)$ from site $1 ; 63 \%$ and $5.86 \pm 0.92(\mathrm{n}=108)$ from site 3 ; and $16.5 \%$ and $0.43 \pm 0.10(n=164)$ from site 4. Also examined were $125 \mathrm{~N}$. stramineus from sites 1,2 , and $3 ; 80 \mathrm{~N}$. dorsalis from sites 1 and 2; 20 Pimephales promelas from site 1;20 Semotilus atromaculatus from site 1; 5 Campostoma anomalum from site 1; 5 Catostomus commersoni from site 3; and 5 Perca flavescens from site 1 . None of these fish was infected.
In experimental infections of 4 definitive host species, $R$. canadensis established and matured only in its natural host $C$. lutrensis. Members of the control and experimental groups were collected from site 1. Prevalence and mean \pm SE for the control group were $46.7 \%$ and $1.53 \pm$ $0.49(\mathrm{n}=15)$, respectively. Experimental red shiners consumed a mean of 5.09 (range: $2-10$ ) infected mayflies, resulting in a prevalence of $100 \%$ and a mean of $14 \pm 2.50 \mathrm{SE}(n=11)$. Differences between these measures were both significant $\left(\chi^{2}=6.14 ; \mathrm{df}=1\right.$ and $\mu=9 ; \mathrm{n}=11$, $15)$.

After infected mayflies were ingested, the juveniles broke free from the capsule and attached to the intestinal mucosa where they continued to develop. Third-stage juveniles were found attached to the intestinal wall of C. lutrensis $24 \mathrm{hr}$ after ingestion of infected mayflies. Development to the fourth stage was observed in 8 days.

Results of experimental infections of $N$. dorsalis, $N$. stramineus, and $F$. zebrinus can be found in Table I. Attachment was observed in N. dorsalis in 2 out of 7 fish used in 2 separate trials. One host harbored 37 third-stage juveniles attached to the anterior portion of the intestine 23 days after feeding. The second fish was infected with 2 third-stage juveniles 4-5 days after feeding. No further development of the juveniles was observed in $N$. dorsalis. Notropis stramineus and $F$. zebrinus did not become infected when fed juveniles of $R$. canadensis.

Survey data presented here clearly show that $R$. canadensis in Nebraska infects a narrow suite of definitive hosts in nature. Only the red shiner was infected. However, due to a small sample size of the common stoneroller $C$. anomalum surveyed, we cannot be certain of its status as a definitive host. Common stonerollers were reported as a host for $R$. canadensis in Texas (Moravec and Huffman, 1988a), so it seems likely that common stonerollers would serve as host for this parasite in Nebraska.

Intermediate host specificity in this system seems to conform to the results presented in previous studies. Only mayfly nymphs were capable of serving as intermediate hosts of $R$. canadensis, and to date no other invertebrate groups have been shown experimentally to serve as intermediate hosts for Rhabdochona spp.

Experimental infections of 3 possible definitive host species not infected in nature showed that both physiological and ecological factors are involved in determining host specificity in na- 
ture. Notropis dorsalis became infected with $R$. canadensis in laboratory infections. Thus, the absence of $R$. canadensis in $N$. dorsalis in nature is ecologically mediated. This hypothesis is supported by the known ecological tendencies of $C$. lutrensis and $N$. dorsalis. In the rivers of $\mathrm{Ne}-$ braska, $C$. lutrensis is usually found along the banks in deep, turbid water among aquatic and fallen terrestrial macrophytes (Matthews, 1985). Notropis dorsalis, on the other hand, is a shallow water fish, found in the flat, middle channels of prairie rivers where little or no vegetation is present. Further, $N$. dorsalis is mainly a benthic feeder, whereas $C$. lutrensis feeds on invertebrates found on or among aquatic vegetation, such as mayflies, stoneflies, and caddisflies (Pflieger, 1975). What is left unanswered is whether $N$. dorsalis can support development of $R$. canadensis to sexual maturity and, thus, under different ecological conditions contribute to the life cycle of this parasite. However, considering the sizeable mean number of parasites per infected mayfly and the fact that bigmouth shiners consumed the fewest number of mayflies and became infected, there is little doubt as to whether sand shiners and plains killish were being exposed to an adequate number of infective nematodes. Thus, the inability to become infected with $R$. canadensis in laboratory infections clearly establishes that the absence of this parasite in $N$. stramineus and F. zebrinus in nature is physiologically mediated.

The authors thank Kathy Keeler and William Scharf for use of Cedar Point Biological Station facilities and equipment. This research was funded in part by a Howard Hughes Medical Institute grant awarded to M.A.B.

\section{LITERATURE CITED}

BYRNE, P. J. 1992. One the biology of Rhabdochona rotundicaudatum and $R$. cascadilla (Nematoda: Thelazioidea) in stream fishes from southern Ontario, Canada. Canadian Journal of Zoology 70: 485-493.

Gustafson, P. V. 1949. Description of some species of Rhabdochona (Nematoda: Thelaziidae). Journal of Parasitology 35: 534-540.

JANISZEWSKA, J. 1960. Studies on larval nematodes in Tubificidae (a hypothesis on the life-cycle of Rhabdochonidae). Acta Parasitologica Polonica 8: 419-425.

MatThews, W. J. 1985. Distribution of midwestern fishes on multivariate environmental gradients, with emphasis on Notropis lutrensis. American Midland Naturalist 113: 225-237.

Moravec, F. 1972. Studies on the development of the nematode Rhabdochona (Filochona) ergensi Moravec, 1968. Folia Parasitologica 19: 321-333.

_ 1976. Observations on the development of Rhabdochona phoxini Moravec, 1968 (Nematoda: Rhabdochonidae). Folia Parasitologica 23: 309320 .

- 1989. Observations on the occurrence and maturation of the nematode Rhabdochona denudata (Dujardin, 1845) in chub, Leuciscus cephalus (L.), of the Rokytna River, Czechoslovakia. Parassitologia 31: 25-35.

- AND H. P. ARAI. 1971. The North and Central American species of Rhabdochona Ralliet 1916 (Nematoda: Rhabdochonidae) of fishes, including Rhabdochona canadensis sp. nov. Journal of Fisheries Research Board Canada 28: 1645-1662.

$\longrightarrow$, AND D. G. HuFFMAN. 1988a. Observations on the genus Rhabdochona Ralliet, 1916 (Nematoda: Rhabdochonidae) from fishes of central Texas, with descriptions of two new subspecies. Folia Parasitologica 35: 341-351.

—, AND —. 1988b. Rhabdochona longley sp. n. (Nematoda: Rhabdochonidae) from blind catfishes, Trogloglanis pattersoni and Satan eurystomus (Ictaluridae) from the subterranean waters of Texas. Folia Parasitologica 35: 235-243.

Muzzall, P. M., G. E. Whelan, AND W. W. TAYlor. 1992. Host-parasite relationships of longnose dace, Rhinichthys cataractae, from the Ford River, Michigan. Journal of Parasitology 78: 837-844.

Pflieger, W. L. 1975. The fishes of Missouri. Missouri Department of Conservation, Jefferson City, Missouri, 343 p.

ShteIN, G. A. 1959. On the question of the life history and living conditions of the nematode Rhabdochona denudata (Dujardin, 1845). Doklady Akademii Nauk SSSR 127: 1320-1321.

VoJTKova, L. 1971. Deitragzur kenntnis der helmintofauna der wasserwirbellosen III. Cestoda, Nematoda, Acanthocephala. Vestnik zoologii 35: 146155.

WelleR, T. H. 1938. Description of Rhabdochona ovifilamenta $\mathrm{n}$. sp. (Nematoda: Thelaziidae) with a note on the life history. Journal of Parasitology 24: 403-408. 